\title{
Morphology, Prevalence and Pathogenicity of Fungi Associated with Diseased Betel Vine (Piper betle L.) in Bangladesh
}

\author{
Md. Zakaria Masud, Md. Rafiqul Islam, Abdullah All Imtiaz, Tahsin Labiba, \\ Md. Raziur Rahman Raihan, Most. Nurjahan Khatun Eaty and Saleh Ahmed Shahriar
}

\section{ABSTRACT}

Three different fungal diseases were found prevalent namely leaf spot, leaf rot, and foot and root rot of betel vine at five different upazillas of five districts in Bangladesh. Phytophthora parasitica causing leaf rot, Colletotrichum piperis causing leaf spot, and Sclerotium rolfsii causing foot and root rot have been found. The highest incidence ( 41.60 per cent) and severity (21.86 per cent) of leaf rot disease were recorded at Mohanpur upazilla during the period of August. Minimum incidence (4.24 per cent) of leaf rot was recorded at Kaligong upazilla while minimum severity $(2.83$ per cent) was recorded at Gouronadi upazilla. The highest incidence of disease ( 57.44 per cent) and severity of disease ( 28.32 per cent) of betel vine leaf spot were recorded at same locations and same period of time as per leaf rot disease. Minimum incidence ( 8.32 per cent) and severity $(2.72$ per cent) of disease were recorded at Sitakundo upazilla during the period of May. In August at Gouranadi upazilla, highest incidence of disease (27.80 per cent) was filed in case of betel vine foot and root rot while the lowest incidence (6.00 per cent) of disease was reported at Sitakundo upazilla. Lesion sizes were varied in ranging $1.4-2.3 \mathrm{~cm}$ in diameter while isolates collected from Mohanpur showed highest pathogenicity caused by Phytophthora parasitica produced lesion $2.3 \mathrm{~cm}$ and lowest pathogenicity was recorded by Sclerotium rolfsii produced lesion $1.4 \mathrm{~cm}$ isolates collected from Mirpur and Mohanpur. In respects of locations and survey period, it was revealed that betel vine leaf rot and leaf spot were prevalent in Mohanpur upazilla during the month of August under Rajshahi district, and betel vine foot and root rot in Gouronadi upazilla under Barisal district.

Keywords: Piper betle L., fungi, diseases, prevalence, pathogenicity.

Published Online: November 30, 2020

ISSN: 2684-5199

DOI :10.24018/ejbio.2020.1.6.124

\section{Md. Zakaria Masud}

Department of Plant Pathology, Sher-eBangla Agricultural University, Dhaka, Bangladesh.

Md. Rafiqul Islam

Department of Plant Pathology, Sher-e-

Bangla Agricultural University, Dhaka, Bangladesh.

Abdullah All Imtiaz

Institute of Seed Technology, Sher-eBangla Agricultural University, Dhaka, Bangladesh.

Tahsin Labiba

Department of Agronomy, Sher-e-Bangla Agricultural University, Dhaka, Bangladesh.

Md. Raziur Rahman Raihan

Faculty of Agriculture, Sher-e-Bangla Agricultural University, Dhaka, Bangladesh.

Most. Nurjahan Khatun Eaty

College of Agricultural Sciences, International University of Business Agriculture and Technology, Dhaka, Bangladesh.

Saleh Ahmed Shahriar*

School of Biological Sciences, Universiti Sains Malaysia, Malaysia.

(e-mail: shahriar777.ss@gmail.com)

*Corresponding Author

\section{INTRODUCTION}

Betel vine (Betle piperis L.) is a perennial rooted climber of the Piperaceae family. The betel vine is cultivated in conservation under the shady and moist conditions are required for proper plant growth. This shady and humid atmosphere also favor the development of various diseases, especially leaf spot of betel vine [1]. Leaves and other plant parts are infected with leaf spot, leaf rot, foot and root rot diseases caused by various fungi. Limitless harm and even complete destruction occurred of all of the betel vine plantations if not managed properly [2], [3]. Among plant microbial pathogens such as bacteria, fungi, viruses, etc., fungi are considered as the most significant and prevalent pathogens, infecting a purview range of plant hosts and causing huge economic loss of field crops and harvesting throughout storage and transport [4]. The diseases cause severe damage in the field to the natural leaves as well as during transit and adverse weather conditions. Betel leaf spot, foot and root rot are serious diseases caused by different fungal pathogens [5]. The major constraint in betel vine cultivation is its diseases that severely damage leaves, foot, stem, root and foliage, play an important role in the growth, propagation and infection, as well as influence the expression of the host plant's susceptibility/resistance after infection. It is cultivated in a rainfall of approximately 225$475 \mathrm{~cm}, \mathrm{RH}$, and regular temp of $40-80$ per cent and 15$90{ }^{\circ} \mathrm{C}$ respectively [6]. Leaf rot will ruin the crop if it infects the vine within a week [7]. Phytophthpra parasitica has recorded leaf rot of betel vine plant can cause leaf yield losses of 30-100 per cent [8]. High relative humidity 
increases the rate of betel vine leaf rot [9]. Though few information are available over controlling the above-listed diseases, the impact of different environmental issues on disease development is not much understood and systematic attempts over these disease epidemiology have not been done so far [10], [11]. The monitoring and management of these pathogens are crucial because betel leaves are one of the most important cash crops in Bangladesh. In addition, the contaminated betel vine leaves often become out of use and people are discouraged in consuming it. Therefore, an investigation should be carried out into betel vine diseases [12]. Bangladesh is the world's second-largest betel vinegrowing country. The total annual production is approximately 72,570 tons and average yield 2.28 tons per acre. Barisal, Maulavi-Bazar, Satkhira, Cox's Bazar, Rajshahi, Jessore, Kushtia, Jhinidah, Pabna etc. are mainly the major betel vine cultivation area of Bangladesh [13]. Betel vine plant is highly vulnerable to disease, pests, and climatic conditions. Diseases are the most important problems for betel vine cultivation. Among the diseases of betel vine, leaf rot caused by Phytophthora parasitica, leaf spot caused by Colletotrichum piparis, and betel vine foot and root rot caused by Sclerotium rolfsii are the major devastating diseases, which decrease the yield of betel vine crop to a huge extent [14]. Leaf rot of betel vine caused by Phytophthora parasitica is an endemic and cause serious problem all over the betel vine growing areas in Bangladesh. Sclerotium rolfsii causing betel vine foot and root rot is a devastating soil borne pathogen with an immense host range [15]. Thus, the investigation was urgently necessary to determine the prevalence of betel vine diseases in major growing areas of Bangladesh. Based on above facts current investigation was undertaken with the following objectives: To detect and morphology of the causal organisms, to estimate the disease incidence (DI) and disease severity (DS) of prevalent diseases and pathogenicity of fungi associated with diseased betel vine.

\section{MATERIALS AND METHODS}

\section{A. Sampling}

The experimental works were done at the Plant Pathology and Seed Pathology Laboratory, Sher-e-Bangla Agricultural University (SAU), Dhaka-1207, Bangladesh. Investigation was conducted at different major betel vine growing locations in Bangladesh. Five upazillas under five districts viz. Gaurnadi, Kaligonj, Kushtia Sadar, Mohanpur, Sitakunda upazilla under Barisal, Jhinaidha, Kustia, Rajshahi and Chittagong district respectively were the surveyed area. Five borojes (betel vine garden) in an upazilla were selected for recording data. The investigation was undertaken to determine the percent disease incidence and severity of different betel vine diseases (leaf rot, leaf spot and foot and root rot) under survey areas. Area of each spots was about $500 \mathrm{sqm}$ of farmers plots. Three visits were made to each spot three times during the study period. Every selected plant was observed, preliminary cleaning of infected samples and then placed in a $4{ }^{\circ} \mathrm{C}$ paper packet in the refrigerator for isolation of Phytophthora parasitica, Colletotrichum piperis and Sclerotium rolfsii [16].

\section{B. Calculation of Disease Incidence}

$\%$ Disease incidence was calculated using below formula [17]:

$\%$ Disease Incidence $=\frac{\text { Number of diseased vine } / \text { stem }}{\text { Total number of inspected vine } / \text { stem }} \times 100$

\section{Calculation of Disease Severity}

$\%$ Disease severity was calculated using following formula [18]:

$0=$ no or a few lesions on leaf,

$1=\mathrm{Up}$ to 10 per cent affected leaf area,

$2=11-25$ per cent affected leaf area,

$3=26-50$ per cent affected leaf area,

$4=51-75$ per cent affected leaf area and

$5=$ above 75 per cent affected leaf area.

$$
\begin{gathered}
\% \text { Disease Severity }=\frac{\text { Total numerical valuses }}{\text { No of inspected vine } / \text { stem }} \times \\
\frac{100}{\text { Maximum rating of disease }}
\end{gathered}
$$

\section{Preparation of Potato Dextrose Agar (PDA) Media}

$250 \mathrm{~g}$ disease free potato were cleaned and washed thoroughly under running tap water. Cleaned potatoes were peeled with sterilized and sharp knife. Peeled potatoes were sliced and then boiled in $1 \mathrm{~L}$ distilled water for 15 mins. It was filtered later using marking cloth. Then $20 \mathrm{~g}$ dextrose and $25 \mathrm{~g}$ straw agar were weighed. Potato broth were filtered with cheese cloth and poured into $1 \mathrm{~L}$ schott bottle filled with dextrose and agar. Then distilled water were added until $1 \mathrm{~L}$ and it was autoclaved by adjusting $121{ }^{\circ} \mathrm{C}$ with 15 PSI pressure for $2 \mathrm{hrs}$.

\section{E. Moist Blotter Method}

Infected betel vine plant parts (leaf / stem) were cut by scissors into several sections and put on Whatman No.1 moist filter paper. Through dipping in sterilized distilled water, three filter paper were moistened. In the incubation chamber the petri dishes with diseased specimens were allowed to incubate for 7 days at $25{ }^{\circ} \mathrm{C}$. After incubation these plates were then examined for preliminary detection of pathogen under compound microscope. The pathogen was transferred and processed to PDA plates using tip culture procedure [12].

\section{F. Isolation in Agar Plate Method}

At first infected parts of the plant (leaf/stem) were thoroughly washed to remove contaminants. Then infected plant parts from the advancing end of the lesions were cut into 4 small pieces $(5 \mathrm{~mm})$. The cut portion was sterilized with 70 per cent alcohol and 1 per cent chlorox $(\mathrm{NaOCl})$ for 3 minutes, and 2 times rinsed with distilled water. Sterilized plant parts were put in petri dishes of $90 \mathrm{~mm}$ on PDA media and allowed to incubate for 7-10 days at room temperature of $22 \pm 2{ }^{\circ} \mathrm{C}$, After 4-5 days the colonies were recorded growing out on PDA [1]. Inoculated petri dishes were observed after incubation period to detect the causal organisms. Based on color and morphology of the colony, subcultures were done by transferring small colony to another Petridish. Pure cultures were made then. Then the 
organisms were isolated by preparing slide under compound microscope and re-cultured to get pure culture of that organism [19].

\section{G. Pathogenicity}

Pathogenicity test was done according to a previous report described by Huq [20]. Collected betel vine leaves and stem were surface sterilized by $70 \%$ alcohol, rinsed with sterile distilled water. Inoculation was done after 7 days incubation period. 3 plants were selected for inoculation in each row by inserting 3 dices of mycelial plug from pure culture plates of Phytophthora parasitica, Colletotrichum piperis and Sclerotium rolfsii were kept covering with moist cotton on leaf / stem. Water was added as per require keeping the cotton moist. Until 2 weeks, symptoms produced by the inoculated plants were observed [21].

\section{H. Data Analysis}

Completely Randomized Design (CRD) for the laboratory and the nursery experiments was followed. The field experiments were followed by Randomized Completely Block Design (RCBD). Data were analyzed for ANOVA using MSTAT-C program [22]. The Least Significance Difference (LSD) test was carried out to determine the level of significant differences and to separate the means within the parameters [23].

\section{RESULTS}

\section{A. Morphological Characteristics}

Phytophthora parasitica produces irregularly shaped and sized spots on leaves, light to dark brown lesions encircled by yellowish halo. Marginal leaf tissues become dark, necrotic, and increasingly spreads toward the middle of the leaf. Diffused yellowish halo were also formed occasionally. Symptoms of leaf spots were shown on artificially inoculated plants. The mean colony growth was reported during a three-day span for all isolates of three fungi on PDA. The growth rate of Phytophthora parasitica isolates ranged between $4.40-14.30 \mathrm{~mm} /$ day. The isolated colonies were white to grayish in color. The size of conidia was within the range of 13-21 $\mu \mathrm{rn}$. Symptoms caused by Colletotrichum piperis, loss of leaves luster in foot rot condition followed by total wilting and drying of the vines occurs in a rapid sequence. The affected plant root system is damaged lateral roots are killed to the complete. Colletotrichum piperis mycelial colony on PDA was circular, raised, and developed white to gray fluffy, colony underside was pink. Average growth of mycelia was recorded $1.17 \times 3.57 \mathrm{~cm} /$ day. Conidia in conidial masses are aseptate, guttulate, initially fusiform, salmon-colored, and $16.2 \times 3.6-6.6 \mu \mathrm{m}$. Affected by Sclerotium rolfsii, betel vine plants showed white mycelial growth near the plant base on soil surface and immature white rounded sclerotia were also observed. Sclerotia were then gradually turned in a color of blue to black and started producing white mycelia. Sclerotium rolfsii average growth rates for the colony were 1.3-1.7 mm per day. Colonies were colored in white to light olive buff. The sclerotial scale of the fungi ranged between 0.6 and $2.2 \mu \mathrm{m}$. Some isolates displayed greater sclerotia (maximum $2.0 \mu \mathrm{m}$ ), and some developed smaller sclerotia (0.50-1.0 $\mu \mathrm{m})$.

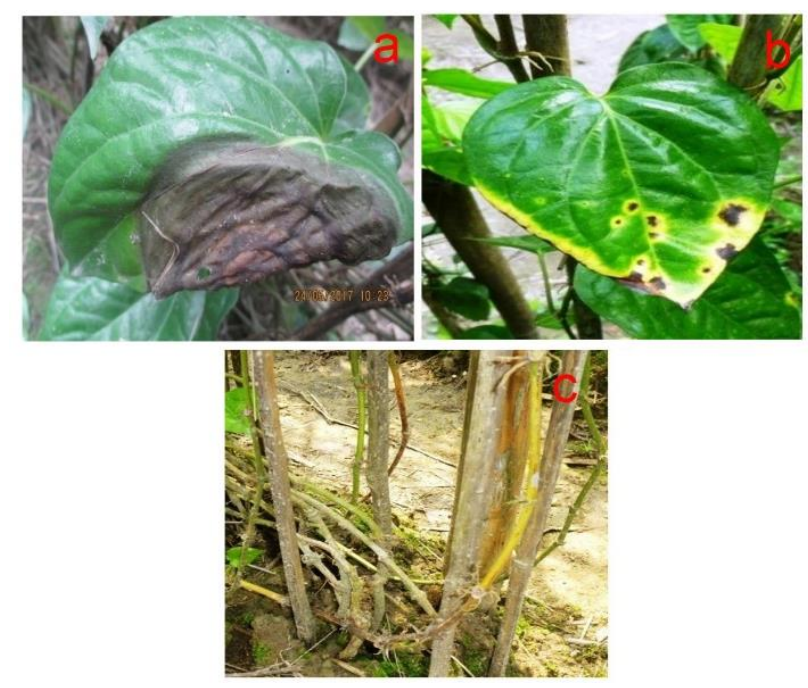

Fig. 1. Symptoms of betel vine diseases (a) Leaf rot caused by Phytophthora parasitica (b) Leaf spot caused by Colletotrichum piparis (c) Foot and root rot caused by Sclerotium rolfsii.

\section{B. (\%) Disease Incidence of Different Betel Vine Disease}

The incidence of betel vine leaf rot in different upazillas was found to differ significantly from one upazilla to another and from one season to the next. Maximum disease incidence (9.76-41.60\%) were under Jhenaidah district. The highest incidence of disease was recorded in August (6.0441.60 per cent), and the lowest in May (4.24-17.60 per cent). Incidence of betel vine leaf spot disease under various upazillas was found to be significantly different from location to location. The highest incidence of disease (11.64-57.44 per cent) was found in Mohanpur upazilla and the lowest in Sitakundu under the district of Chittagong (8.32-20.16 per cent). The highest recorded in Mohanpur upazilla under Rajshahi district and minimum (4.24-34.48 per cent) in Kaligonj upazilla incidence of disease was observed in August (13.92-57.44 per cent), and the lowest in May (8.32-11.64 per cent). The incidence of betel vine foot and root rot under various upazillas differed significantly from one location to another, and from one season to another. The highest incidence of disease (19.60-27.80 per cent) was found at Gouranadi upazilla of Barisal district and lowest disease incidence (6.0-17.0 per cent) was found in Sitakunda upazilla under Chittagong district. The highest incidence of disease was recorded in August (17.0-27.80 per cent), and the lowest in May (6.0-19.60 per cent). Jahan et al., 2016 [21] reported maximum disease incidence of foot and root rot ranging from 54.00-64.00 per cent and 46.0052.00 per cent in July and October month, respectively and minimum disease incidence was recorded ranging from 28.00-34.00 per cent and 20.00-28.00 per cent in July and October month, respectively. Data are presented in Table 1. 
TABLE 1: DISEASE INCIDENCE OF DIFFERENT BETEL VINE DISEASES

\begin{tabular}{|c|c|c|c|}
\hline \multirow{2}{*}{ Locations } & \multicolumn{3}{|c|}{ \% Disease Incidence (Month wise) } \\
\hline & January & May & August \\
\hline \multicolumn{4}{|c|}{ Leaf rot (Phytophthora parasitica) } \\
\hline Gouranadi & $14.40 \mathrm{c}$ & $7.68 \mathrm{bc}$ & $9.36 \mathrm{c}$ \\
\hline Kaligonj & $21.44 \mathrm{~b}$ & $4.24 \mathrm{c}$ & $34.48 \mathrm{ab}$ \\
\hline Mirpur & $17.68 \mathrm{bc}$ & $17.60 \mathrm{a}$ & $34.24 \mathrm{~b}$ \\
\hline Mohanpur & $27.28 \mathrm{a}$ & $9.76 \mathrm{~b}$ & $41.60 \mathrm{a}$ \\
\hline Sitakunda & $14.88 \mathrm{c}$ & $6.96 \mathrm{bc}$ & $6.04 \mathrm{c}$ \\
\hline $\mathrm{LSD}_{0.05}$ & 5.691 & 3.588 & 7.344 \\
\hline $\mathrm{CV}(\%)$ & 22.18 & 28.94 & 21.78 \\
\hline \multicolumn{4}{|c|}{ Leaf spot (Colletotrichum piperis) } \\
\hline Gouranadi & $12.28 \mathrm{~d}$ & $8.96 \mathrm{c}$ & $14.40 \mathrm{~d}$ \\
\hline Kaligonj & $20.88 \mathrm{a}$ & $10.36 \mathrm{~b}$ & $40.40 \mathrm{c}$ \\
\hline Mirpur & $20.04 \mathrm{a}$ & $10.80 \mathrm{ab}$ & $50.40 \mathrm{~b}$ \\
\hline Mohanpur & $18.24 \mathrm{a}$ & $11.64 \mathrm{a}$ & $57.44 \mathrm{a}$ \\
\hline Sitakunda & $20.16 \mathrm{a}$ & $8.32 \mathrm{c}$ & $13.92 \mathrm{~d}$ \\
\hline $\mathrm{LSD}_{0.05}$ & 3.212 & 1.088 & 6.048 \\
\hline $\mathrm{CV}(\%)$ & 13.08 & 8.11 & 17.77 \\
\hline \multicolumn{4}{|c|}{ Foot and root rot (Sclerotium rolfsii) } \\
\hline Gouranadi & $21.20 \mathrm{a}$ & $19.60 \mathrm{a}$ & $27.80 \mathrm{a}$ \\
\hline Kaligonj & $18.40 \mathrm{ab}$ & $15.20 \mathrm{ab}$ & $24.60 \mathrm{ab}$ \\
\hline Mirpur & $7.80 \mathrm{c}$ & $11.20 \mathrm{bc}$ & $22.40 \mathrm{abc}$ \\
\hline Mohanpur & $7.80 \mathrm{c}$ & $10.00 \mathrm{bc}$ & $20.00 \mathrm{bc}$ \\
\hline Sitakunda & $9.40 \mathrm{bc}$ & $6.00 \mathrm{c}$ & $17.00 \mathrm{c}$ \\
\hline $\mathrm{LSD}_{0.05}$ & 7.536 & 6.708 & 6.132 \\
\hline $\mathrm{CV}(\%)$ & 55.05 & 39.96 & 20.45 \\
\hline
\end{tabular}

\section{C. (\%) Disease Severity of Different Betel Vine Diseases}

Disease severity of betel vine leaf rot was found to vary significantly from one location to another, and season to season under different upazillas. The maximum severity of the disease (5.42-21.86 percent) was observed under Rajshahi district in Mohanpur upazilla, and the minimum severity of the disease (1.80-18.14 percent) was identified under Jhinaidah district in Kaligonj upazilla. The highest severity of the disease was observed in August (5.34$21.86 \%)$, and the lowest in May (1.80-8.08\%). The severity of betel vine leaf spot disease under various upazillas ranged significantly from place to place and season to season. The maximum severity of the disease (4.82-28.32 percent) was observed under Rajshahi district in Mohanpur upazilla, and the minimum severity of the disease (2.72-4.97 percent) was reported under Barisal district in Gouranadi upazilla. The highest severity of the disease was observed in August $(4.97-28.32 \%)$, and the lowest in May $(2.72-4.82 \%)$. Jahan et al., 2016 [21] reported maximum disease severity of foot and root rot ranging from 34.00-35.60 percent and 32.5033.90 percent in July and October month, respectively and minimum disease severity was recorded ranging from 18.6019.50 percent and $16.70-18.10$ percent in July and October month, respectively. Data are presented in Table 2.

TABLE 2: DISEASE SEVERITY OF DIFFERENT BETEL VINE DISEASES

\begin{tabular}{|c|c|c|c|}
\hline \multirow{2}{*}{ Locations } & \multicolumn{3}{|c|}{ \% Disease Severity (Month wise) } \\
\hline & January & May & August \\
\hline \multicolumn{4}{|c|}{ Leaf rot (Phytophthora parasitica) } \\
\hline Gouranadi & $7.63 \mathrm{~b}$ & $2.83 \mathrm{c}$ & $5.34 \mathrm{c}$ \\
\hline Kaligonj & $10.94 \mathrm{~b}$ & $1.80 \mathrm{c}$ & $18.14 \mathrm{~b}$ \\
\hline Mirpur & $9.65 \mathrm{~b}$ & $8.08 \mathrm{a}$ & $18.62 \mathrm{~b}$ \\
\hline Mohanpur & $14.58 \mathrm{a}$ & $5.42 \mathrm{~b}$ & $21.86 \mathrm{a}$ \\
\hline Sitakunda & $7.52 \mathrm{~b}$ & $2.84 \mathrm{c}$ & $9.61 \mathrm{c}$ \\
\hline $\mathrm{LSD}_{0.05}$ & 3.509 & 1.84 & 3.22 \\
\hline $\mathrm{CV}(\%)$ & 26.01 & 32.76 & 17.78 \\
\hline \multicolumn{4}{|c|}{ Leaf spot (Colletotrichum piperis) } \\
\hline Gouranadi & $4.94 \mathrm{c}$ & $2.75 \mathrm{bc}$ & $4.97 \mathrm{~b}$ \\
\hline Kaligonj & $10.17 \mathrm{ab}$ & $4.25 \mathrm{ab}$ & $23.38 \mathrm{a}$ \\
\hline Mirpur & $9.00 \mathrm{~b}$ & $3.77 \mathrm{abc}$ & $25.81 \mathrm{a}$ \\
\hline Mohanpur & $12.02 \mathrm{a}$ & $4.82 \mathrm{a}$ & $28.32 \mathrm{a}$ \\
\hline Sitakunda & $11.58 \mathrm{ab}$ & $2.72 \mathrm{c}$ & $6.27 \mathrm{~b}$ \\
\hline $\mathrm{LSD}_{0.05}$ & 2.670 & 1.51 & 8.348 \\
\hline $\mathrm{CV}(\%)$ & 20.86 & 31.42 & 35.08 \\
\hline
\end{tabular}

\section{Pathogenicity Results}

Lesions size caused by Phytophthora parasitica was varied in ranging $1.5-2.3 \mathrm{~cm}$ in diameter. Isolates from Mohanpur Upazilla revealed highly pathogenic produced lesions size $2.3 \mathrm{~cm}$ while lowest in Gouranadi $(1.5 \mathrm{~cm})$. For Colletotrichum piperis, lesions sizes were varied from 1.6$2.1 \mathrm{~cm}$. Isolates of Kaligonj Upazilla showed highest pathogenicity produced lesion size $2.1 \mathrm{~cm}$ while lowest was found in Gouranadi $(1.6 \mathrm{~cm})$. In case of Sclerotium rolfsii, ranging lesion sizes $1.4-2.2 \mathrm{~cm}$ was recorded while highest was found in Gourandi $(2.2 \mathrm{~cm})$ and lowest in Mirpur (1.4 $\mathrm{cm})$. Data are presented in Table 3. Koch's postulates subjected pathogenicity studies to Phytophthora parasitica, Colletotrichum piperis and Sclerotium rolfsii, isolated from diseased betel vine samples. The inoculated plants showed typical symptoms. Artificially inoculated plant parts are then allowed to grow mycelia and lesions on PDA media at room temperature in incubation chamber. Thus, the re-isolated pathogens were Phytophthora parasitica, Colletotrichum piperis and Sclerotium rolfsii showed their characteristics colony appearance and were responsible for causing leaf spots, leaf rot and foot and root rot, respectively [21]. Data are presented in Table 3 .

TABLE 3: RESULTS OF PATHOGENICITY TESTS

\begin{tabular}{|c|c|c|}
\hline Locations & Lesions sizes $(\mathrm{cm})$ & Pathogenic indication \\
\hline \multicolumn{3}{|c|}{ Leaf rot (Phytophthora parasitica) } \\
\hline Gouranadi & $1.5 \mathrm{c}$ & Low \\
\hline Kaligonj & $2.1 \mathrm{~b}$ & Highly \\
\hline Mirpur & $1.8 \mathrm{bc}$ & Moderate \\
\hline Mohanpur & $2.3 \mathrm{a}$ & Highly \\
\hline Sitakunda & $1.6 \mathrm{c}$ & Low \\
\hline $\operatorname{LSD}_{0.05}$ & \multicolumn{2}{|c|}{0.13} \\
\hline $\mathrm{CV}(\%)$ & \multicolumn{2}{|c|}{3.70} \\
\hline \multicolumn{3}{|c|}{ Leaf spot (Colletotrichum piperis) } \\
\hline Gouranadi & $1.6 \mathrm{c}$ & Low \\
\hline Kaligonj & $2.1 \mathrm{a}$ & Highly \\
\hline Mirpur & $2.0 \mathrm{~b}$ & Highly \\
\hline Mohanpur & $1.8 \mathrm{bc}$ & Moderate \\
\hline Sitakunda & 2.0 & Highly \\
\hline $\mathrm{LSD}_{0.05}$ & \multicolumn{2}{|c|}{0.13} \\
\hline $\mathrm{CV}(\%)$ & \multicolumn{2}{|c|}{3.57} \\
\hline \multicolumn{3}{|c|}{ Foot and root rot (Sclerotium rolfsii) } \\
\hline Gouranadi & $2.2 \mathrm{a}$ & Highly \\
\hline Kaligonj & $1.8 \mathrm{bc}$ & Moderate \\
\hline Mirpur & $1.4 \mathrm{c}$ & Low \\
\hline Mohanpur & $1.4 \mathrm{c}$ & Low \\
\hline Sitakunda & $1.5 \mathrm{~b}$ & Low \\
\hline $\mathrm{LSD}_{0.05}$ & \multicolumn{2}{|c|}{0.11} \\
\hline $\mathrm{CV}(\%)$ & \multicolumn{2}{|c|}{3.36} \\
\hline
\end{tabular}

\section{DISCUSSION}

Betel vine (Piper betle L.) is susceptible to be attacked by many diseases at all growth stages. In Bangladesh the diseases of betel vine were studied to a limited extent. High humid and moist shaded conditions are for the growth of betel vine. This is also favorable to develop betel vine diseases. The foot and root rot of betel vine was found worldwide including Indonesia, Myanmar, Sri Lanka, and Bangladesh etc. The highest intensity of foot and root rot and leaf rot has been recorded in West Bengal [20]. $29{ }^{\circ} \mathrm{C}$ temperature and $85 \% \mathrm{RH}$, is needed for high disease incidence and severity of foot and root rot of betel vine in Satkhira district [13]. The infection of foot and root rot of betel vine usually does not extend beyond one or two internodes because the plant dies before the disease 
progresses. The average losses by foot and root rot may vary from $30-100 \%$ [8]. Islam (2005) [12] observed that $60 \%$ of betel leaf production decreased in three upazilas of Rajshahi due to foot and root rot disease. Phytophthora sp. can attack stem portion of betel vine. In betel vines, Phytophthora induced leaf rot associated with wilting is common. The two types of spots are found in leaf rot disease of betel vine [8]. The betel vine reported to attack Phytophthora sp. includes $P$. nicotianae var. parasitica, $P$. nicotianae var. piperina and $P$. parasitica, /P. palmivora [8]. Based on existing keys to Phytophthora spp. all the isolates from Assam were identified as Phytophthora palmivora. 16 isolates of Phytophthora parasitica were identified from different betel vine growing areas of West Bengal. In case of leaf rot, average losses $20-40 \%$ [4]. Foot and root rot of betel vine caused by Sclerotium rolfsii is a soil borne fungus with a wide range of agronomical and horticultural crops. S. rolfsii is also a facultative saprophytic fungus and can produce resting spore (sclerotium) under unfavorable Climate. Mollah (2012) [13] observed sclerotial wilt of betel vine in Chittagong. Plants showed decay at the collar region. The infected portion of stem was covered with white cottony mycelia strands with small, light to deep brown sclerotia on the stem as well as adjacent soil surface. Chattapadhyay and Maity (1967) [24] observed 35 to $39 \%$ disease incidence of S. rolfsii on Piper betle in different areas of Karnataka province during 1984-85. Amin et al., 2013 [25] reported that the any amount of Sclerotium rolfsii can produce collar rot and wilt disease of betel vines. Jahan et al., 2016 [21] proved the pathogenicity of Sclerotium rolfsii in betel leaf by inoculating 7 days old sclerotial cultures in sand corn meal medium and observed the symptoms one week after inoculation.

\section{CONCLUSION}

In respect of different locations and period of survey it is revealed that leaf rot (Phytophthora parasitica), Leaf spot (Colletotrichum piperis) and foot and root rot (Sclerotium rolfsii) of betel vine were prevalent in the month of August at Mohanpur upazilla under Rajshahi district, Sitakundo upazilla under Chittagong district and Gouronadi upazilla under Barisal district, respectively. From the findings of this current study it may be concluded that betel vine leaf rot, leaf spot and foot and root rot are the three most prevalent diseases in various upazillas of selected areas and there was a higher prevalence in August and a lower prevalence in May, regardless of the different betel vine growing locations under surveyed areas. Further investigations are needed to justify the present findings for consecutive years.

\section{ACKNOWLEDGMENTS}

We acknowledge financial support from Sher-e-Bangla Agricultural University, Sher-e-Bangla Nagar, Dhaka-1207, Bangladesh.

\section{REFERENCES}

[1] Haider, M. R., Khair, A., Rahman, M. M. and Alam, M. K. (2013). Indigenous management practices of betel-leaf (Piper betel L.) cultivation by the Khasia community in Bangladesh. Indian Journal of Traditional Knowledge, 12(2), 231-239.

[2] Chattapadhyay, S. B. \& Maity, S. (1990). Diseases of betel vine and spices. Indian Council of Agricultural Research, New Delhi. p. 160.

[3] Tuite, J. (1969). Plant Pathological Methods. Fungi and Bacteria Burgess Pub. Co. Minneapolis, Minn. USA. p. 293.

[4] Hassan, S. A. and Shahadat, S. (2005). Disease affecting betel vine. Journal of Plant Development Science, 3(2), 4-5.

[5] Srivastava M. and D. V. Singh. (1994). Epidemiology of leaf rot and foot rot of betel vine caused by Phytophthora parasitica at Mahoba. Indian J. Plant Pathol. 12 (1\&2): 10-12.

[6] Guha, P. and Jain. (1997). Paan Theke Kutir shilpa shambhabana (In Bengali) Exploring Betel Leaves for Cottage Industriy. pp15-19.

[7] Chaurasia J. P. (1994). Studies on the management of BetelvinePhytophthora disease in Sagar division. Ph.D. Thesis, Dr. H. S. Gour University. Sagar. 110pp.

[8] Maiti S. and Sen C. (1979). Leaf rot and foot rot of Piper betel caused by Phytophthora palmivora. Indian Phytopath. 30: 438-439.

[9] Kumar C. P. C. and Kumar C. S. K. (2004). Epidemiological studies on Phytophthora foot rot disease of betel vine. Indian J. Plant Protection. 32 (2): 100-101.

[10] Goswami B. K., Kader, K. A., Rahman M. L., Islam, M. R. and Malaker, P. K. (2002). Development of leaf spot of betelvine caused by Colletotrichum capsici. Bangladesh J. Plant Pathol. 18(1\&2): 3942.

[11] Sayeeduzzaman, M. (1988). An economic geographical study of betel leaf cultivation in Bangladesh. A M.Sc. thesis submitted to Geography, University of Dhaka. pp. 45-47.

[12] Islam, M. (2005). Country news, Holiday Publication Limited. 8: 3-4.

[13] Mollah, M. I. (2012). Investigation on the leaf rot and foot and root rot of betel vine (Piper betel L.) in Satkhira district of Bangladesh. MS Thesis, Dept. of Plant Pathology, Sher-e-Bangla Agricultural University, Sher-e-Bangla Nagar, Dhaka-1207.

[14] Samanta, C. (1994). A Report on Problem and Solutions of Betelvine Cultivation. A booklet published by Mr. H. R. Adhikarri, C-2/16 Karunamoyee, Salt Lake City, Kolkata- 64 (WB), India.

[15] Talukder, M. (1974). Plant diseases of Bangladesh. Bangladesh J. of Agril. Res., 1(1), 64-68.

[16] Maity P. (1989). Extension Bulletin: The Betel vine. All India coordinated Researh project of betel vine. Indian Institute for Horticultural Research. Hessarghatta, Bangalore, India.

[17] Rai, V.R. and Mamatha, T. (2005). Seedling diseases of some important forest tree species and their management. A working paper of the finish forest research institute. India. p. 11.

[18] Goswami B. K., Zahid M. I. and Haq, M. O. (1993). Screening of Colocasia esculenta germplasm to Phytophthora leaf blight. Bangladesh J. Plant Pathol. 9(1\&2): 21-24.

[19] Marimuthu, T. and R. Rabindran. (1988). Influence of weather factors on the incidence of foot rot and leaf rot of betelvine. Indian Phytopath. 41: 373-375.

[20] Huq, M.I. (2011). Studies on the epidemiology of leaf rot and leaf spot diseases of betel vine (Piperbetle L.). Bangladesh J. Sci. Ind. Res. 46(4): 519-522.

[21] Jahan, A., Islam, M. R., Rahman, M. M., Rashid, M. H. \& Adan, M. J. (2016). Investigation on foot and root rot of betel vine (Piper betel L.) in Kushtia district of Bangladesh. J. Biosci and Agril Res. 07(01), 590-599.

[22] MSTAT. (1991). User's manual for MSTAT-C. Michigan State University, East Lansing, Michigan. p. 450.

[23] Gomez, K. A. \& Gomez, A. A. (1984). Statistical procedure for agricultural research. Second Edn. Intl. Rice Res. Inst. John Wiley and Sons. New York. pp. 1-340.

[24] Chattapadhyay, S. P. and Maity, S. (1967). Diseases of Betelvine and species. ICAR New Delhi.

[25] Amin, R., Sarker, B. C., Adhikary, S. K., Sultana, S. \& Zubair, T. (2013). Effect of some botanical extracts and cow's urine on Sclerotium rolfsii causal agent of foot and root rot of betel vine. The International Journal of Engineering and Science, 2(9), 77-82. 